\title{
Numerical development of lead-free Cs2 TiI6-based perovskite solar cell via SCAPS-1D
}

\author{
Ilyas Chabri $^{1, *}$, Ali Oubelkacem ${ }^{1}$, and Youness Benhouria ${ }^{1}$ \\ ${ }^{1}$ Laboratory of Physics of Materials and Modeling of Systems, (LP2MS), Physics Department, Faculty of Science, University Moulay \\ Ismail, Meknes, Morocco
}

\begin{abstract}
Because of the toxicity and stability concerns, commercialization of lead-based perovskite solar cells (PSCs) is limited. Solar cells made entirely of Ti-based all-inorganic perovskite could be a viable answer to these issues. This paper is a theoretical paper on a perovskite solar cell (PSC) based on $\mathrm{Cs}_{2} \mathrm{TiI}_{6}$ using all-inorganic charge transport materials. We proposed a high performance perovskite solar cell (PSC) according to variables such as charge transport materials and its optimal thicknesses, absorber thickness, absorber defect density and interface defect density and working temperature. The optimal absorber thickness, Hole transport layer (HTL) thickness, and Electron transport layer (ETL) thickness are $500 \mathrm{~nm}$, $50 \mathrm{~nm}$, and $10 \mathrm{~nm}$, respectively. After analyzing the other factors, we ended up with a high-performance PSC with a power conversion efficiency of $22.5 \%$ at room temperature and $22.84 \%$ at $270 \mathrm{~K}$. These results are useful for the conception and manufacture of PSCs.
\end{abstract}

\section{Introduction}

Organic-inorganic perovskite materials have been extensively explored in recent years as an alternative to silicon-based solar cells for improving device efficiency, and it are a potential alternative to silicon-based solar cells because of its lower manufacturing costs [1,2]. Since the 2012 breakthroughs [3,4], it is now generally agreed that the halide perovskite solar cells could have a significant practical influence in the future generation solar cells. The active material of a typical perovskite solar cell was an organic-inorganic halide material $[5,6]$. Jena et al. developed the perovskite solar cell (PSC) by employing an organic-inorganic lead halide as an absorber instead of an organic dye [7]. From 2009 to 2019, the PCE (power conversion efficiency) of a typical organic-inorganic hybrid PSC (perovskite solar cell) has risen from $3.8 \%$ to over $25 \%$. Despite the excellent optoelectronic properties of organic-inorganic hybrid PSCs, they display three major problems. For starters, it reduce the shelf life of perovskite compounds. Second, the presence of organic cations creates instability, and third, they use a lead $(\mathrm{Pb})$-based absorber, which is environmentally damaging [8]. As a result, all inorganic lead-free halide-based PSCs are now introduced [9]. As with organic-inorganic hybrid absorber, organic charge transport become unstable in oxygen, sunlight, and humidity [10,11]. Chen and his colleagues developed $\mathrm{Cs}_{2} \mathrm{TiBr}_{6}$ thin film Perovskites with a $3.28 \%$ solar efficiency [12].
Because of its potential light harvesting properties, acceptable bandgap, good optical absorption, high stability, and benign defect property, $\mathrm{Cs}_{2} \mathrm{TiI}_{6}$ absorber material is shown to be a suitable alternate. The $\mathrm{Cs}_{2} \mathrm{TiI}_{6}$ absorber can be more resistant to environmental stress and have better tolerance [12],13]. Ahmed et al. reported an $\mathrm{FTO} / \mathrm{SnO}_{2} / \mathrm{Cs}_{2} \mathrm{TiBr}_{6} / \mathrm{MoO}_{3} / \mathrm{Au}$ structure, with a stable PCE up to $11.49 \%$ [14]. Ahmad and his colleagues suggested an unique perovskite solar cell configuration of $\mathrm{Au} / \mathrm{CdTe} / \mathrm{Cs}_{2} \mathrm{TiI}_{6} / \mathrm{TiO}_{2} / \mathrm{ITO}$, which has a PCE of $15.06 \%$ [15].

In this study, we propose an all-inorganic PSC with a new combination of $\mathrm{FTO} / \mathrm{ZnO} / \mathrm{Cs}_{2} \mathrm{TiI}_{6} / \mathrm{MoO}_{3} / \mathrm{Au}$ using (SCAPS 1D-3.3.10). We analyzed the effects of various inorganic charge transport materials to find the optimum material for $\mathrm{Cs}_{2} \mathrm{TiI}_{6}$-based PSC, e.g., p- $\mathrm{MoO}_{3}$, p-CuI, p$\mathrm{NiO}, \mathrm{n}-\mathrm{TiO}_{2}, \mathrm{n}-\mathrm{SnO}_{2}, \mathrm{n}-\mathrm{ZnO}, \mathrm{n}-\mathrm{CdS}$ as HTL (Hole Transport Layer) and ETL (Electron Transport Layer) and optimized its thicknesses for achieving optimum performance. We also studied the effect of defect density of $\mathrm{Cs}_{2} \mathrm{TiI}_{6}$, defect density of the interface, and the effect of operating temperature on device performance. Upon comparing the performance parameters, e.g., short circuit $\mathrm{J}_{\mathrm{sc}}$ (current density), $\mathrm{V}_{\mathrm{oc}}$ (open-circuit voltage), PCE (power conversion efficiency), and FF (Fill Factor), we have obtained an optimized high-performance PSC with a novel combination of $\mathrm{FTO} / \mathrm{ZnO} / \mathrm{Cs}_{2} \mathrm{TiI}_{6} / \mathrm{MoO}_{3} / \mathrm{Au}$, that may aid in designing eco-friendly Ti-based perovskite solar cell for future technologies.

\footnotetext{
* Corresponding author: i.chabri@umi.ac.ma
} 


\section{Theoretical simulation}

$\mathrm{FTO} / \mathrm{ETL} /$ perovskite/HTL/Au is a unidimensional ni-p planar heterojunction composition in our modeled PSC structure (Fig. 1). In this structure, we used inorganic lead-free $\mathrm{Cs}_{2} \mathrm{TiI}_{6}$ as PAL (perovskite active layer), inorganic n- $\mathrm{TiO}_{2}, \mathrm{n}-\mathrm{SnO}_{2}, \mathrm{n}-\mathrm{ZnO}$, and n-CdS as ETL (electron transport layer), and inorganic p- $\mathrm{MoO}_{3}$, p-CuI, and p-NiO as HTL (hole transport layer). For validation of our simulation, we first simulated the $\mathrm{FTO} / \mathrm{TiO}_{2} / \mathrm{Cs}_{2} \mathrm{TiBr}_{6}(200 \mathrm{~nm}) / \mathrm{P} 3 \mathrm{HT} / \mathrm{Au}$ structure using the SCAPS 1D simulation software and then compared it to the experimental results [12]. HTL and ETL thicknesses of $30 \mathrm{~nm}$ are determined by calibrating simulation data with experimental data.

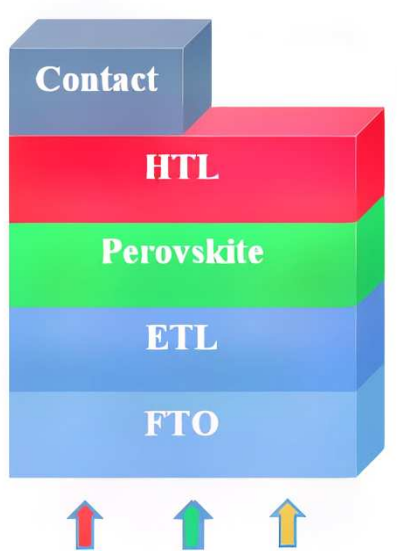

Sun light

Fig. 1. Schematic of the simulated n-i-p perovskite solar cell

Table 1. Input parameters for each layer of the PSC structure

\begin{tabular}{|c|c|c|c|c|}
\hline & FTO & $\mathrm{TiO}_{2}$ & $\mathrm{Cs}_{2} \mathrm{TiBr}_{6}$ & P3HT \\
\hline Thickness, d (nm) & 500 & 30 & 200 & 30 \\
\hline Band gap, $E_{g}(e V)$ & 3.5 & 3.2 & 1.8 & 2 \\
\hline Electron affinity, $\chi(\mathrm{eV})$ & 4 & 4.1 & 4 & 3.2 \\
\hline Permittivity, $\varepsilon_{r}$ & 9 & 9 & 10 & 3 \\
\hline Effective density states at $\mathrm{CB}, \mathrm{N}_{\mathrm{c}}\left(\mathrm{cm}^{-3}\right)$ & $2.2 \mathrm{E}+18$ & $2.2 \mathrm{E}+18$ & $6 \mathrm{E}+19$ & $1 \mathrm{E}+20$ \\
\hline Effective density states at $\mathrm{VB}, \mathrm{N}_{\mathrm{v}}\left(\mathrm{cm}^{-3}\right)$ & $1.8 \mathrm{E}+19$ & $1 E+19$ & $2.14 \mathrm{E}+19$ & $1 \mathrm{E}+20$ \\
\hline Electron mobility, $\mu_{n}\left(\mathrm{~cm}^{2} / \mathrm{V} s\right)$ & 20 & 20 & 0.236 & 0.0001 \\
\hline Hole mobility, $\mu_{\mathrm{p}}\left(\mathrm{cm}^{2} / \mathrm{V} \mathrm{s}\right)$ & 10 & 10 & 0.171 & 0.0001 \\
\hline Density of n-type doping, $N_{D}\left(\mathrm{~cm}^{-3}\right)$ & $1 \mathrm{E}+19$ & $1 \mathrm{E}+18$ & $3 \mathrm{E}+19$ & 0 \\
\hline Density of p-type doping, $N_{A}\left(\mathrm{~cm}^{-3}\right)$ & 0 & 0 & $3 \mathrm{E}+18$ & $1 \mathrm{E}+16$ \\
\hline Defect density, $\mathrm{N}_{\mathrm{t}}\left(\mathrm{cm}^{-3}\right)$ & - & $1 \mathrm{E}+15$ & $4.17 \mathrm{E}+15$ & $1 \mathrm{E}+15$ \\
\hline Capture cross-section electrons $\left(\mathrm{cm}^{2}\right)$ & - & $2 \mathrm{E}-14$ & $1 \mathrm{E}-15$ & $1 \mathrm{E}-15$ \\
\hline Capture cross-section holes $\left(\mathrm{cm}^{2}\right)$ & - & $2 \mathrm{E}-14$ & $1 \mathrm{E}-15$ & $1 \mathrm{E}-15$ \\
\hline Reference & {$[16]$} & {$[12],[17]$} & {$[12]$} & {$[12,16]$} \\
\hline
\end{tabular}

FTO and Au have work functions of $4.4 \mathrm{eV}$ and 5.1 $\mathrm{eV}$, respectively. We used the following settings for all defect layers: At $300 \mathrm{~K}$, the thermal velocity of electrons and holes is $10^{7} \mathrm{~cm} / \mathrm{s}$, the energy distribution is Gaussian, the characteristic energy is $0.1 \mathrm{eV}$, and the energy level relative to the reference is $0.6 \mathrm{eV}$ [18]. We provided absorber/ETL and absorber/HTL interface defects with hole capture cross section of $10^{-18} \mathrm{~cm}^{2}$ and $10^{-19} \mathrm{~cm}^{2}$, electron-capture cross section of $10^{-19} \mathrm{~cm}^{2}$ and $10^{-18} \mathrm{~cm}^{2}$ respectively, and interface defect density of $10^{13} \mathrm{~cm}^{-3}$. We took a constant illumination of $1000 \mathrm{~W} / \mathrm{m}^{2}$ at AM $1.5 \mathrm{G}$, a continuous temperature of $300 \mathrm{~K}$, a series resistance of $1 \Omega-\mathrm{cm}^{2}$, and a shunt resistance of $4200 \Omega$ $\mathrm{cm}^{2}$ to perform the simulation.

Table 2. Comparison between simulated and experimental $\mathrm{Cs}_{2} \mathrm{TiBr}_{6}$ based solar cells using P3HT as HTM

\begin{tabular}{ccccc}
\hline $\begin{array}{c}\text { Device } \\
\text { Architecture }\end{array}$ & $\begin{array}{c}\mathbf{J}_{\mathbf{s c}} \\
\left(\mathbf{m A} / \mathbf{c m}^{\mathbf{2}}\right)\end{array}$ & $\begin{array}{c}\mathbf{V}_{\text {oc }} \\
(\mathbf{V})\end{array}$ & $\begin{array}{c}\text { FF } \\
(\boldsymbol{\%})\end{array}$ & $\begin{array}{c}\text { PCE } \\
(\%)\end{array}$ \\
\hline $\begin{array}{c}\text { (Experiment) } \\
\text { [12] }\end{array}$ & 3.87 & 0.89 & 59.5 & 2.05 \\
(Simulation) & 3.78 & 0.9 & 50.01 & 1.71 \\
\hline
\end{tabular}

Fig. 2 depicts the energy band diagram and J-V plots of the simulated $\mathrm{FTO} / \mathrm{TiO}_{2} / \mathrm{Cs}_{2} \mathrm{TiBr}_{6} / \mathrm{P} 3 \mathrm{HT} / \mathrm{Au}$ structure. Table 2 shows the performance comparison between the simulated and experimental structure. The simulation results are clearly in agreement with the relevant experimental results. This also means that the simulation parameters are nearly identical to those of a real device.

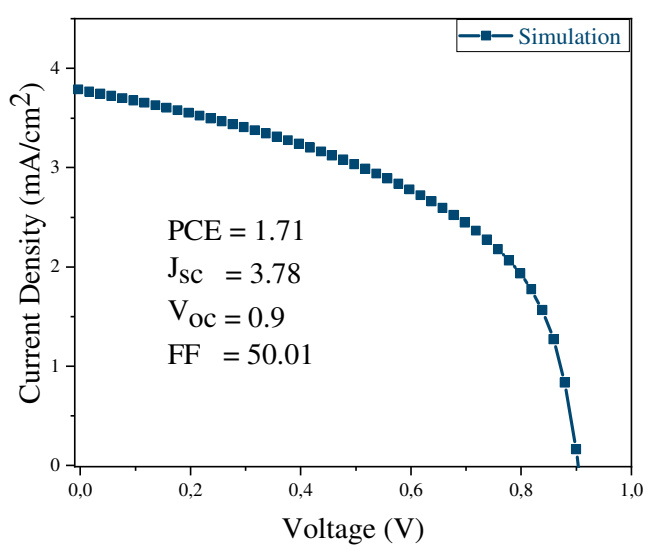

Fig. 2. J-V curve for $\mathrm{FTO} / \mathrm{TiO}_{2} / \mathrm{Cs}_{2} \mathrm{TiBr}_{6} / \mathrm{P} 3 \mathrm{HT}$ 


\section{Results and discussion}

In this paper, analyzing several HTMs (Hole Transport Materials) and ETMs (Electron Transport Materials) by optimizing its thicknesses and, also by optimizing the density of PAL defects and interface defects, we propose a new structure $\mathrm{FTO} / \mathrm{ZnO} / \mathrm{Cs}_{2} \mathrm{TiI}_{6} /$ $\mathrm{MoO}_{3} / \mathrm{Au}$.

\subsection{HTL optimization}

Instead of using organic P3HT as an HTM, we now select the most suited HTM and calculate its optimal thickness using inorganic $\mathrm{CuI}, \mathrm{MoO}_{3}$, and NiO. Table 3 shows the input values for several HTMs.

Table 3. Parameter settings for several HTMs, ETMs and for the PSC structure's absorber

\begin{tabular}{|c|c|c|c|c|c|c|c|}
\hline & p-CuI & p-NiO & p-MoO3 & Cs2TiI6 & $\mathrm{n}-\mathrm{SnO}_{2}$ & $\mathrm{n}-\mathrm{ZnO}$ & n-CdS \\
\hline Thickness, d (nm) & 30 & 30 & 30 & 200 & 30 & 30 & 30 \\
\hline Band gap, $\mathbf{E}_{\mathrm{g}}(\mathrm{eV})$ & 3.1 & 3.8 & 3 & 1.80 & 3.5 & 3.3 & 2.4 \\
\hline Electron affinity, $\chi(\mathrm{eV})$ & 2.1 & 1.46 & 2.5 & 4.20 & 4 & 4.1 & 4.18 \\
\hline Permittivity, $\varepsilon_{r}$ & 6.5 & 10.7 & 12.5 & 18.0 & 9 & 9 & 10 \\
\hline Effective density states at $\mathrm{CB}, \mathrm{N}_{\mathrm{c}}\left(\mathrm{cm}^{-3}\right)$ & $\begin{array}{c}2.8 \mathrm{E}+1 \\
9\end{array}$ & $2.8 \mathrm{E}+19$ & $2.2 \mathrm{E}+18$ & $1.0 \mathrm{E}+19$ & $2.2 \mathrm{E}+17$ & $\begin{array}{c}2.2 \mathrm{E}+1 \\
8\end{array}$ & $2.2 \mathrm{E}+18$ \\
\hline Effective density states at $\mathrm{VB}, \mathrm{N}_{\mathrm{v}}\left(\mathrm{cm}^{-3}\right)$ & $1 \mathrm{E}+19$ & $1 \mathrm{E}+19$ & $1.8 \mathrm{E}+19$ & $1.0 \mathrm{E}+19$ & $2.2 \mathrm{E}+16$ & $\begin{array}{c}1.9 \mathrm{E}+1 \\
9\end{array}$ & $1.9 \mathrm{E}+19$ \\
\hline Electron mobility, $\mu_{n}\left(\mathrm{~cm}^{2} / \mathrm{V} \mathrm{s}\right)$ & 100 & 12 & 25 & 4.4 & 20 & 100 & 100 \\
\hline Density of p-type doping, $\mathrm{N}_{\mathrm{A}}\left(\mathrm{cm}^{-3}\right)$ & 43.9 & 2.8 & 100 & 2.5 & 10 & 25 & 25 \\
\hline Density of n-type doping, $\mathrm{ND}_{D}\left(\mathrm{~cm}^{-3}\right)$ & 0 & 0 & 0 & $1 \mathrm{E}+19$ & $1 \mathrm{E}+18$ & $1 \mathrm{E}+18$ & $1 \mathrm{E}+18$ \\
\hline Density of p-type doping, $\mathrm{N}_{\mathrm{A}}\left(\mathrm{cm}^{-3}\right)$ & $1 \mathrm{E}+18$ & $1 \mathrm{E}+18$ & $1 \mathrm{E}+18$ & $1 \mathrm{E}+19$ & 0 & 0 & 0 \\
\hline Defect density, $\mathrm{N}_{\mathrm{t}}\left(\mathrm{cm}^{-3}\right)$ & $1 \mathrm{E}+15$ & $1 \mathrm{E}+15$ & $1 \mathrm{E}+15$ & $1 \mathrm{E}+15$ & $1 \mathrm{E}+15$ & $1 \mathrm{E}+15$ & $1 \mathrm{E}+15$ \\
\hline Capture cross-section electrons $\left(\mathrm{cm}^{2}\right)$ & $1 \mathrm{E}-15$ & $1 \mathrm{E}-15$ & $1 \mathrm{E}-15$ & $1 \mathrm{E}-15$ & $2 \mathrm{E}-14$ & $2 \mathrm{E}-14$ & $2 \mathrm{E}-14$ \\
\hline Capture cross-section holes $\left(\mathrm{cm}^{2}\right)$ & $1 \mathrm{E}-15$ & $1 \mathrm{E}-15$ & $1 \mathrm{E}-15$ & $1 \mathrm{E}-15$ & $2 \mathrm{E}-14$ & $2 \mathrm{E}-14$ & $2 \mathrm{E}-14$ \\
\hline Reference & {$[19]$} & [19] & {$[20]$} & {$[15,21]$} & [17] & [17] & [22] \\
\hline
\end{tabular}

The measurements for several HTMs are shown in table 4, and fig 3 shows the corresponding J-V characteristics for each HTM employed in the device. When compared to the performances of other HTMs, $\mathrm{MoO} 3$ has better $\mathrm{J}-\mathrm{V}$ characteristics, a higher $\mathrm{V}_{\mathrm{oc}}$, and a higher PCE.

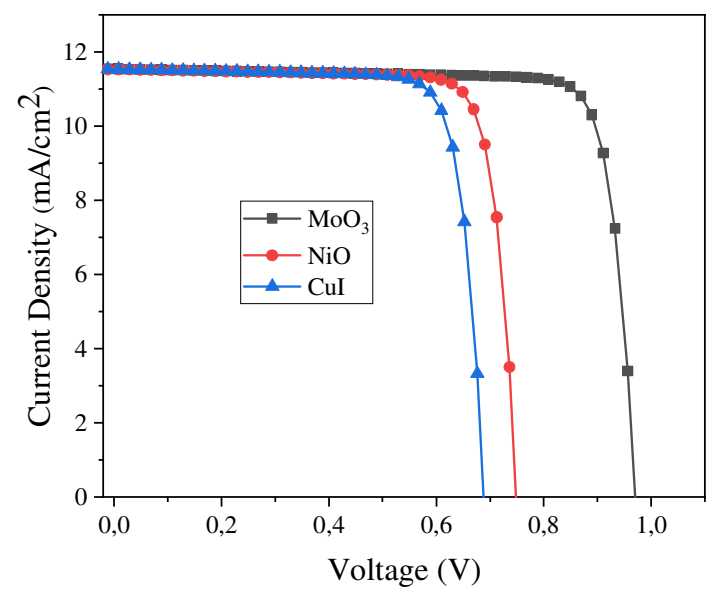

Fig. 3. J-V characteristics curve for several HTLs
Table 4. Performance parameters of several HTLs

\begin{tabular}{ccccc}
\hline $\begin{array}{c}\text { Hole } \\
\begin{array}{c}\text { Transport } \\
\text { Material }\end{array}\end{array}$ & $\begin{array}{c}\mathrm{J}_{\mathrm{sc}} \\
\left(\mathrm{mA} / \mathrm{cm}^{2}\right)\end{array}$ & $\begin{array}{c}\mathrm{V}_{\mathrm{oc}} \\
(\mathrm{V})\end{array}$ & $\begin{array}{c}\mathrm{FF} \\
(\%)\end{array}$ & $\begin{array}{c}\mathrm{PCE} \\
(\%)\end{array}$ \\
\hline $\mathrm{MoO}_{3}$ & 11.53 & 0.97 & 83.88 & 9.4 \\
$\mathrm{CuI}$ & 11.53 & 0.69 & 80.76 & 6.42 \\
$\mathrm{NiO}$ & 11.52 & 0.75 & 81.92 & 7.08 \\
\hline
\end{tabular}

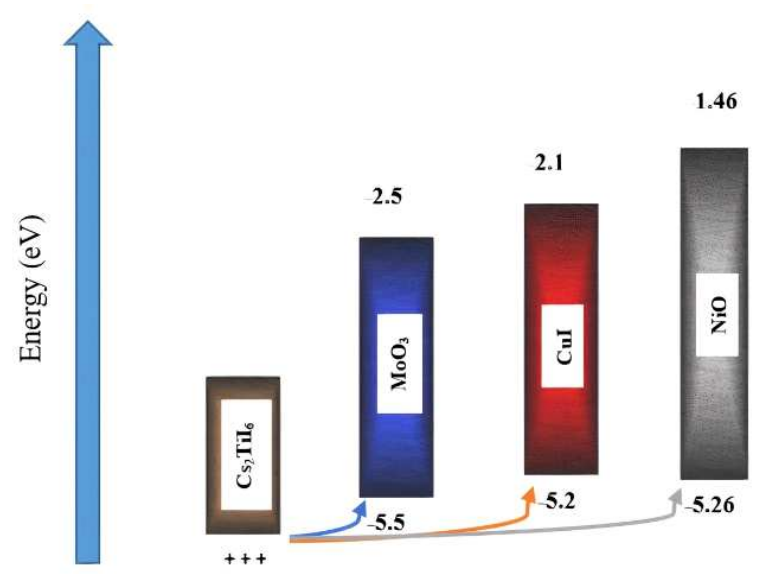

Fig. 4. Energy level of $\mathrm{Cs}_{2} \mathrm{TiI}_{6}$ and HTMs

The Valance Band Offset (VBO) for all HTMs is negative, as seen in Fig. 4. When VBO is negative, there is no barrier to photo-generated holes flowing toward the back electrode, hence $\mathrm{J}_{\mathrm{sc}}$ is nearly constant. $\mathrm{J}_{\mathrm{sc}}$ is found to be $11.52 \mathrm{~mA} / \mathrm{cm}^{2}$ for $\mathrm{NiO}, 11.53 \mathrm{~mA} / \mathrm{cm}^{2}$ for $\mathrm{CuI}$ and 
$\mathrm{MoO}_{3}$. However, the increase in negative VBO causes an increase in interface recombination, which reduces $\mathrm{V}_{\mathrm{oc}}$ [23]. We find $\mathrm{V}_{\text {oc }}$ is $0.97 \mathrm{~V}, 0.69 \mathrm{~V}$, and $0.75 \mathrm{~V}$ for $\mathrm{MoO}_{3}, \mathrm{CuI}$, and $\mathrm{NiO}$ respectively. For $\mathrm{MoO}_{3}, \mathrm{CuI}$, and $\mathrm{NiO}$, the $\mathrm{V}_{\text {oc }}$ is $0.97 \mathrm{~V}, 0.69 \mathrm{~V}$, and $0.75 \mathrm{~V}$, respectively. When it is increased, negative VBO decreases FF from $83.88 \%$ to $81.92 \% . \mathrm{MoO}_{3}$ has the highest $\mathrm{PCE}=9.4 \%$ because it has the lowest negative VBO, i.e. best band alignment with $\mathrm{Cs}_{2} \mathrm{TiI}_{6}$. PCE declines to $7.08 \%$ when negative $\mathrm{VBO}$ increases in $\mathrm{NiO}$. CuI, on the other hand, has the largest negative $\mathrm{VBO}$, indicating poor band alignment, and lowest PCE of $6.42 \%$ [23].

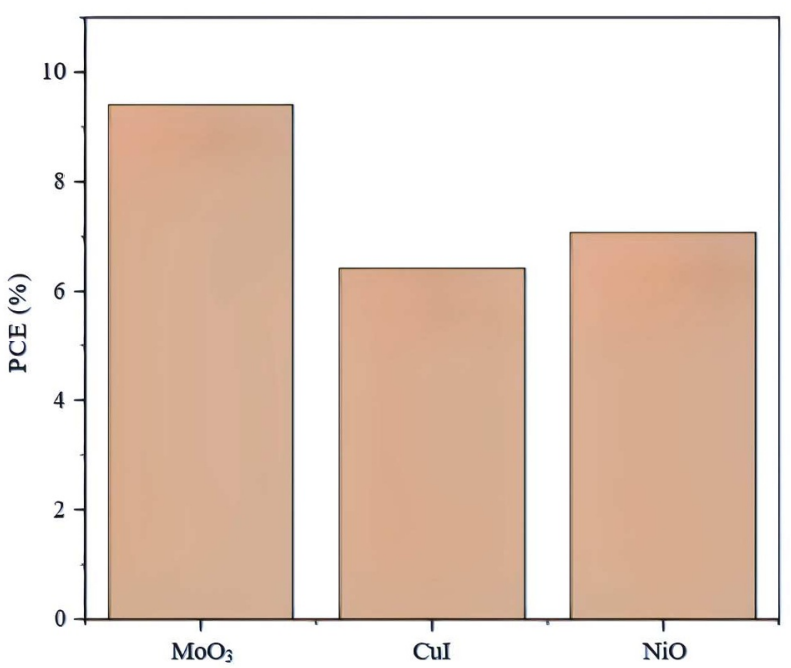

Fig. 5. PCE for several HTLs

The structure of $\mathrm{MoO}_{3}$ has the best PCE, as shown in Fig. 5, so we picked $\mathrm{MoO}_{3}$ to optimize the thickness. We changed the HTL thickness from $20 \mathrm{~nm}$ to $50 \mathrm{~nm}$ to optimize the HTL thickness taking in mind the regular feasibility of the perovskite solar cell construction process [24], and its effect is shown in Fig. 6. It can be found that with the increase in the HTL thickness, the values of $\mathbf{J}_{\mathrm{sc}}$ decreases gradually. $\mathrm{V}_{\mathrm{oc}}$ increases when the thickness is smaller than $35 \mathrm{~nm}$ and then it remained almost unchanged. The FF and PCE of the device first increase when the HTL thickness is less than $50 \mathrm{~nm}$ and then decrease slightly with further increasing the HTL thickness. This is because when the HTL is too thin, it may lead to low shunt resistance and current leakage, thus resulting in a low FF [25]. However, when the HTL is too thick, the series resistance will increase, leading to a reduction in FF. The structure using $\mathrm{MoO}_{3}$ as $\mathrm{HTM}$ provides the best performance at $50 \mathrm{~nm}$ having $\mathrm{V}_{\text {oc }} \square$ $0.97 \mathrm{~V}, \mathrm{~J}_{\mathrm{sc}}=11.54 \mathrm{~mA} / \mathrm{cm}^{2}, \mathrm{FF}=84.06 \%$, and $\mathrm{PCE}=$ $9.46 \%$. Therefore, we select $\mathrm{MoO}_{3}$ as the optimum HTM for $\mathrm{Cs}_{2} \mathrm{TiI}_{6}$ based PSC with an optimized thickness of $50 \mathrm{~nm}$.

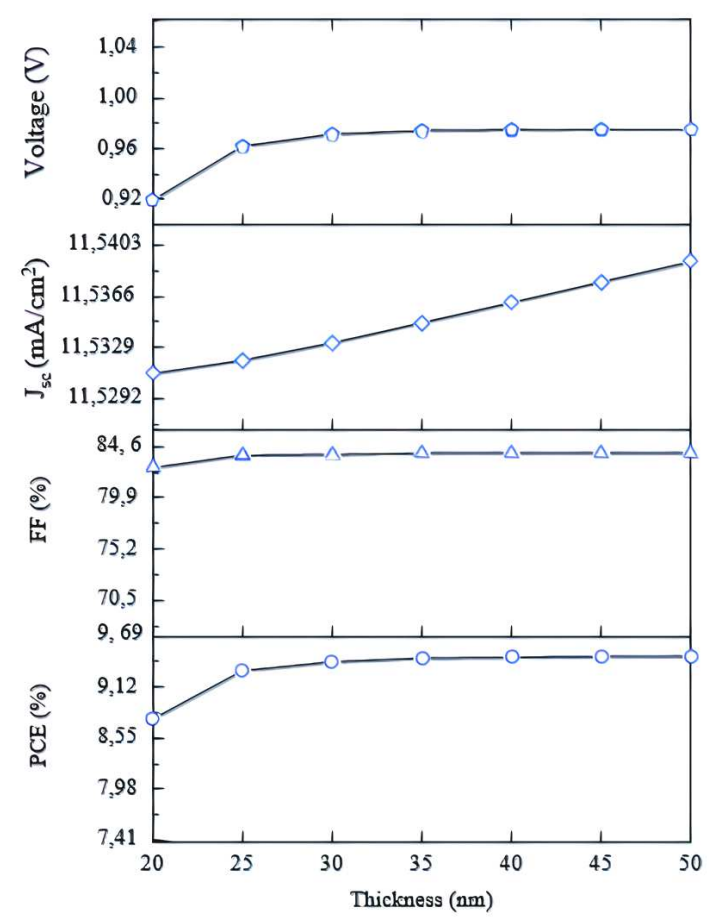

Fig. 6. HTL thickness optimization curve for $\mathrm{MoO}_{3}$

\subsection{Absorber thickness optimization}

We have optimized the absorber thickness by using optimized $\mathrm{MoO}_{3}$ as HTL. We have varied the absorber thickness from 300-520 nm using inorganic $\mathrm{TiO}_{2}, \mathrm{SnO}_{2}$, $\mathrm{ZnO}$, and $\mathrm{CdS}$ as ETMs underneath the perovskite. Tables 1 and 3 provide the input parameters of the ETMs. Fig. 7 displays the optimization of the absorber thickness for different ETMs. It shows that the use of $\mathrm{TiO}_{2}$ and $\mathrm{ZnO}$ provides both the best results than other ETMs, with a PCE of $12.01 \%$, but using $\mathrm{ZnO}$ gives a better $\mathrm{J}_{\mathrm{sc}}$ than using $\mathrm{TiO}_{2}$. The other parameters; $\mathrm{V}_{\mathrm{oc}}$ and FF are almost the same for all ETMs. So we chose $\mathrm{ZnO}$ as ETL, with optimal absorber thickness of $500 \mathrm{~nm}$. The reason for this better PCE of $\mathrm{ZnO}$ can be elicited from Fig. 8.

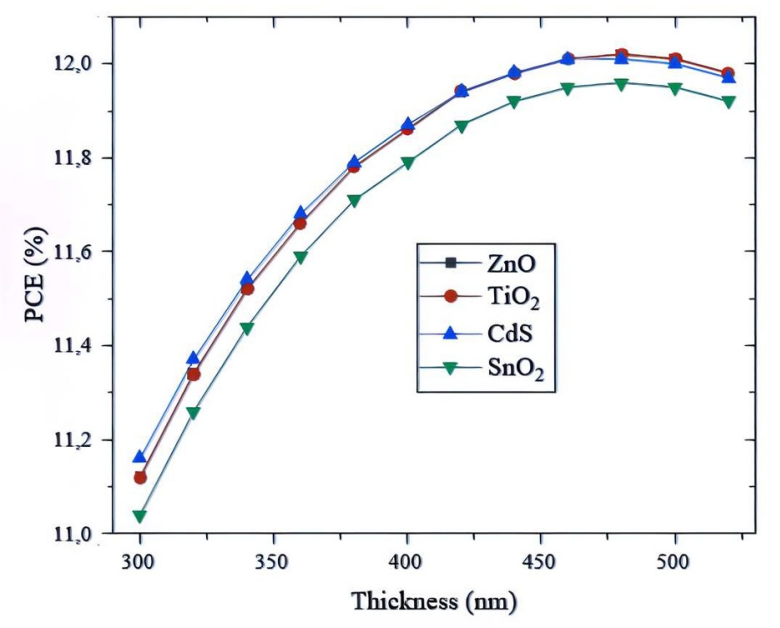

Fig. 7. PCE curve against thickness variation of the $\mathrm{Cs}_{2} \mathrm{TiI}_{6}$ absorber for different ETMs. 
Table 5. Output parameters for ETMs of the PSC structure

\begin{tabular}{ccccc}
\hline $\begin{array}{c}\text { Electron } \\
\text { Transport } \\
\text { Material }\end{array}$ & $\begin{array}{c}\mathbf{J}_{\mathbf{s c}} \\
\left(\mathbf{m A} / \mathbf{c m}^{2}\right)\end{array}$ & $\mathbf{V}_{\text {oc }}(\mathbf{V})$ & $\begin{array}{c}\mathbf{F F} \\
(\%)\end{array}$ & $\begin{array}{c}\text { PCE } \\
(\boldsymbol{\%})\end{array}$ \\
\hline $\mathrm{ZnO}$ & 16.402363 & 0.9805 & 74.68 & 12.01 \\
$\mathrm{TiO}_{2}$ & 16.402336 & 0.9805 & 74.68 & 12.01 \\
$\mathrm{CdS}$ & 16.415707 & 0.9804 & 74.55 & 12.00 \\
$\mathrm{SnO}_{2}$ & 16.301709 & 0.9804 & 74.75 & 11.95 \\
\hline
\end{tabular}

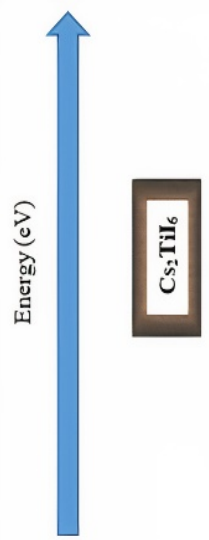

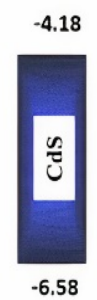
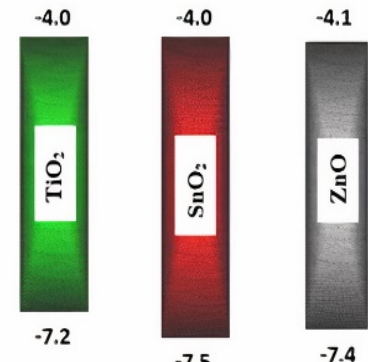

Fig. 8. Energy level diagram of the absorber and different ETMs

In Fig. 8 , the conduction band offset $(\mathrm{CBO})$ is negative for all ETMs. When $\mathrm{CBO}$ is negative, $\mathrm{V}_{\mathrm{oc}}$ decreases monotonically. The negative CBO being very small there is no effect on the value of $\mathrm{V}_{\mathrm{oc}}$ and FF [14]. According to literature, all the ETMs have a good band alignment with the absorber. So we should have obtained a constant $\mathbf{J}_{\mathrm{sc}}[23]$.

However, we obtain $\mathrm{J}_{\mathrm{sc}} 16.415707 \mathrm{~mA} / \mathrm{cm}^{2}$ for $\mathrm{CdS}$, $16.402336 \mathrm{~mA} / \mathrm{cm}^{2}$ for $\mathrm{TiO}_{2}, 16.402363 \mathrm{~mA} / \mathrm{cm}^{2}$ for $\mathrm{ZnO}$ and, $16.301709 \mathrm{~mA} / \mathrm{cm}^{2}$ for $\mathrm{SnO}_{2}$ due to the variation in its quantum efficiency $(\mathrm{QE})$ which is shown in Fig. 9. As $\mathrm{J}_{\mathrm{sc}}$ varies, the PCE of structure using different ETMs also varies.

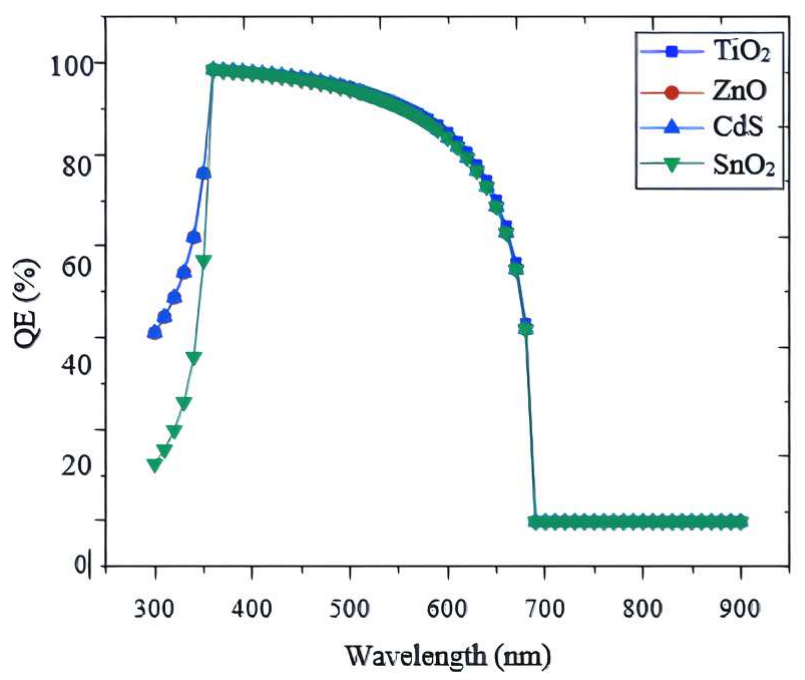

Fig. 9. Quantum efficiency curves for various ETMs at optimal absorber thickness.

From Fig. 9, we find the $\mathrm{CdS}, \mathrm{TiO}_{2}, \mathrm{SnO}_{2}$, and $\mathrm{ZnO}$ exhibit as much as $98.75 \%, 98.72 \%, 98.69 \%$, and 98.72 $\%$ QE respectively in the visible range. Therefore, $\mathrm{ZnO}$ possesses $\mathrm{J}_{\mathrm{sc}}$ of $16.402363 \mathrm{~mA} / \mathrm{cm}^{2}$ and thus the best PCE. Therefore, we select the optimized Perovskite Active Layer (PAL) thickness to be $500 \mathrm{~nm}$ for $\mathrm{ZnO}$ as ETL.

\subsection{ETL thickness optimization}

We optimized the $\mathrm{ZnO}$ thickness by varying it from $10 \mathrm{~nm}$ to $55 \mathrm{~nm}$ as ETL using the optimal HTL and PAL thicknesses. As shown in Fig. 10, there was no significant improvement in the output parameters when the ETL thickness was varied. As a result, we choose the optimized thickness of $10 \mathrm{~nm}$ with the highest PCE $12.02 \%, \mathrm{~V}_{\mathrm{oc}} 0.9805 \mathrm{~V}, \mathrm{~J}_{\mathrm{sc}} 16.402430 \mathrm{~mA} / \mathrm{cm}^{2}$, and FF $74.71 \%$. 


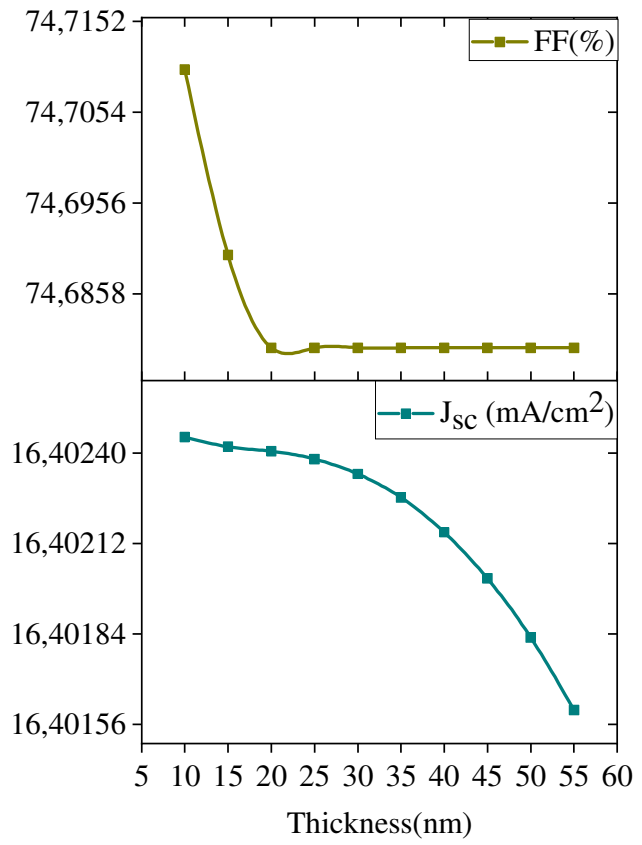

Fig. 10. Variations in $J_{\mathrm{sc}}$ and FF as a function of ETL thickness

\subsection{Absorber defect density optimization}

We have studied the impacts of defect density by varying it from $10^{11} \mathrm{~cm}^{-3}$ to $10^{16} \mathrm{~cm}^{-3}$ using selected ETM and HTM, as well as optimal HTL, PAL, and ETL thicknesses. The J-V curves at various defect densities are seen in Fig. 11. The $\mathbf{J}_{\mathrm{sc}}$ of PSC degrades from $16.50 \mathrm{~mA} / \mathrm{cm}^{2}$ for $10^{12} \mathrm{~cm}^{-3}$ to $16.26 \mathrm{~mA} / \mathrm{cm}^{2}$ for $10^{16} \mathrm{~cm}^{-3}$. The increase in the recombination rate as defect density increases is the source of this degradation [26]. When the defect density is less than $10^{12} \mathrm{~cm}^{-3}$, however, it remains almost constant. As a result, we chose a defect density of $10^{12} \mathrm{~cm}^{-3}$, with a $\mathrm{V}_{\mathrm{oc}}$ of $0.9886 \mathrm{~V}$, and $\mathrm{J}_{\mathrm{sc}}$ of $16.50 \mathrm{~mA} / \mathrm{cm}^{2}$.

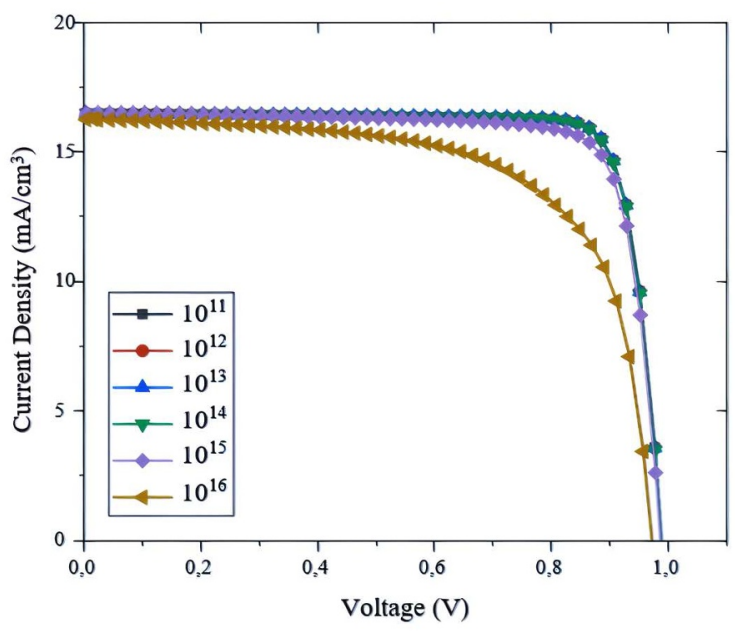

Fig. 11. J-V curve comparison for various absorber defect densities

\subsection{Optimization of the defect density at the interface}

$\mathrm{J}-\mathrm{V}$ characteristics for different defect densities at the interfaces for values between $10^{4} \mathrm{~cm}^{-3}$ and $10^{9} \mathrm{~cm}^{-3}$ are shown in Fig. 12. $\mathrm{V}_{\mathrm{oc}}$ saturates at defect densities below $10^{5} \mathrm{~cm}^{-3}$, as shown in this diagram. $\mathrm{V}_{\mathrm{oc}}$, on the other hand, decreases from $1.63 \mathrm{~V}$ to $1.4 \mathrm{~V}$ above $10^{5} \mathrm{~cm}^{-3}$ to $10^{9} \mathrm{~cm}^{-3}$. As a result, at $10^{5} \mathrm{~cm}^{-3}$, we choose the optimum interface defect with $\mathrm{V}_{\mathrm{oc}}$ of $1.63 \mathrm{~V}, \mathrm{~J}_{\mathrm{sc}}$ of $16.50 \mathrm{~mA} / \mathrm{cm}^{2}$, FF of $83.42 \%$ and PCE of $22.50 \%$.

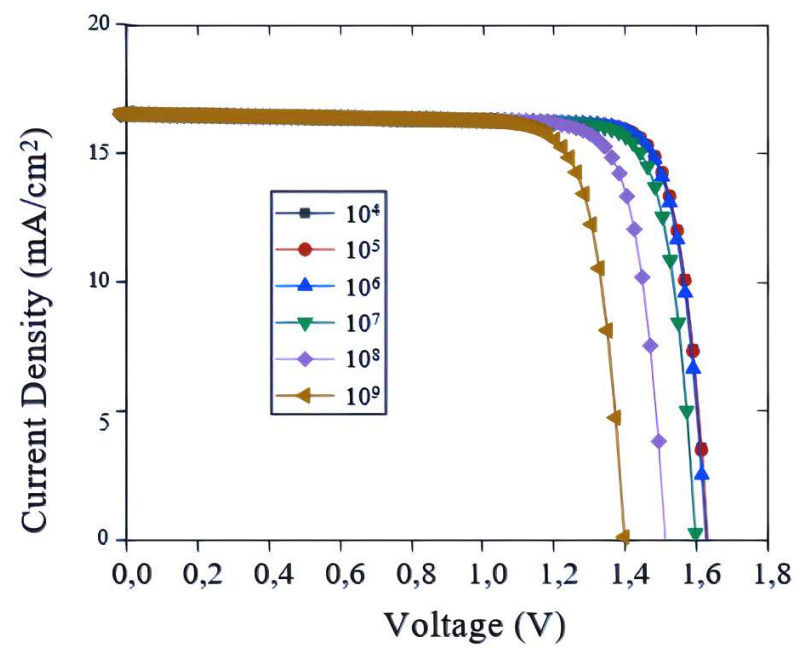

Fig. 12. Comparison of J-V curve for different interface defects

\subsection{Optimized device}

We achieved a high performance PSC with a new combination of $\mathrm{FTO} / \mathrm{ZnO} / \mathrm{CsTiI}_{6} / \mathrm{MoO}_{3} / \mathrm{Au}$ after optimizing HTL, PAL, and ETL. The new structure's schematic is shown in Figure 13.

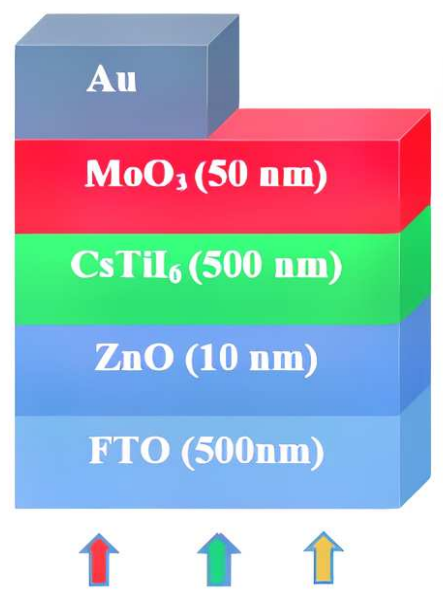

Sun light

Fig. 13. The optimized novel structure FTO/ZnO/Cs $2 \mathrm{TiI}_{6} / \mathrm{MoO}_{3} / \mathrm{Au}$ 

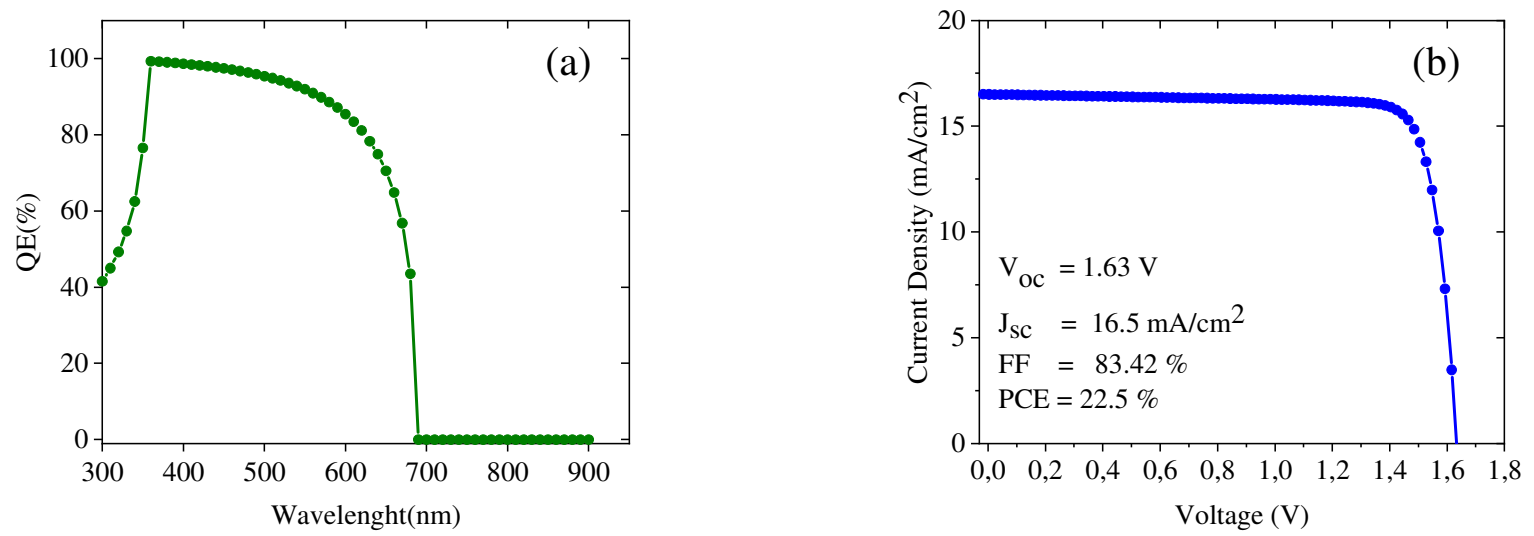

Fig. 14. (a) J-V characteristics curve, (b) QE curve, for optimized FTO/ZnO/Cs2 $\mathrm{TiI}_{6} / \mathrm{MoO}_{3} / \mathrm{Au}$ structure

The J-V characteristics curve and the QE curve for the optimized device are shown in Fig.14. The device offers a PCE of $22.5 \%, \mathrm{~J}_{\mathrm{sc}}$ of $16.5 \mathrm{~mA} / \mathrm{cm}^{2}, \mathrm{~V}_{\mathrm{oc}}$ of 1.63 $\mathrm{V}$, and $\mathrm{FF}$ of $83.42 \%$ with a $99.28 \%$ QE at $360 \mathrm{~nm}$, in the visible range. Table 6 compares the performance of different lead-free PSC studies. It can be seen that our device produces comparatively promising results, it's eco-friendly because it is made entirely of inorganic $\mathrm{Ti}$ based perovskite materials, and that it is expected to be highly stable in the environment due to the use of all inorganic charge transport layers.

Table 6. Performance of several lead-free PSC

\begin{tabular}{ccc}
\hline Absorber & PCE & Ref \\
\hline $\mathrm{CsSnI}_{3}$ & 4.81 & {$[27]$} \\
$\mathrm{CsSnBr}_{3}$ & 3.04 & {$[26]$} \\
$\mathrm{CsSnCl}_{3}$ & 9.66 & {$[28]$} \\
$\mathrm{CsSnBr}_{3}$ & 10.46 & {$[28]$} \\
$\mathrm{CsGeI}_{3}$ & 4.94 & {$[29]$} \\
$\mathrm{CsGeBr}_{3}$ & 4.92 & {$[29]$} \\
$\mathrm{CsGeCl}_{3}$ & 2.57 & {$[28]$} \\
$\mathrm{CsSn}_{0.5} \mathrm{Ge}_{0.5} \mathrm{I}_{3}$ & 7.11 & {$[30]$} \\
$\mathrm{CsSnIBr}_{2}$ & 3.2 & {$[31]$} \\
$\mathrm{CsSnI}_{3}$ & 2.3 & {$[32]$} \\
$\mathrm{Cs}_{2} \mathrm{TiBr}_{6}$ & 11.49 & {$[14]$} \\
$\mathrm{Cs}_{2} \mathrm{TiI}_{6}$ & 15.06 & {$[15]$} \\
$\mathrm{Cs}_{2} \mathrm{TiI}_{\mathbf{6}}$ & $\mathbf{2 2 . 5}$ & This \\
\hline
\end{tabular}

\subsection{Working Temperature effect}

To understand the effect of temperature on our new device, and the suitable temperature to get the best PCE, we changed the working temperature from $270 \mathrm{~K}$ to $360 \mathrm{~K}$. Fig. 16 shows that as the working temperature rises from $270 \mathrm{~K}$ to $360 \mathrm{~K}$, the $\mathrm{V}_{\text {oc }}$ decreases from $1.6585 \mathrm{~V}$ to $1.5790 \mathrm{~V}$. This is due to the fact that when the temperature rises, the saturation current and recombination rate increase. Additionally, due of the thermal generation of carriers and the reduction of the band gap, $\mathrm{J}_{\mathrm{sc}}$ increases from $16.503854 \mathrm{~mA} / \mathrm{cm}^{2}$ to $16.504397 \mathrm{~mA} / \mathrm{cm}^{2}$ [33]. The FF decreases from $83.43 \%$ to $81.63 \%$ as the rate of increase in $\mathrm{J}_{\mathrm{sc}}$ is less than the rate of decrease in $\mathrm{V}_{\mathrm{oc}}$, and the PCE reduces from $22.84 \%$ to $21.27 \%$. The overall performance of the PSC degrades when PCE decreases [34]. So the device gives a better performance for $270 \mathrm{~K}$, it can be used especially in cold regions.

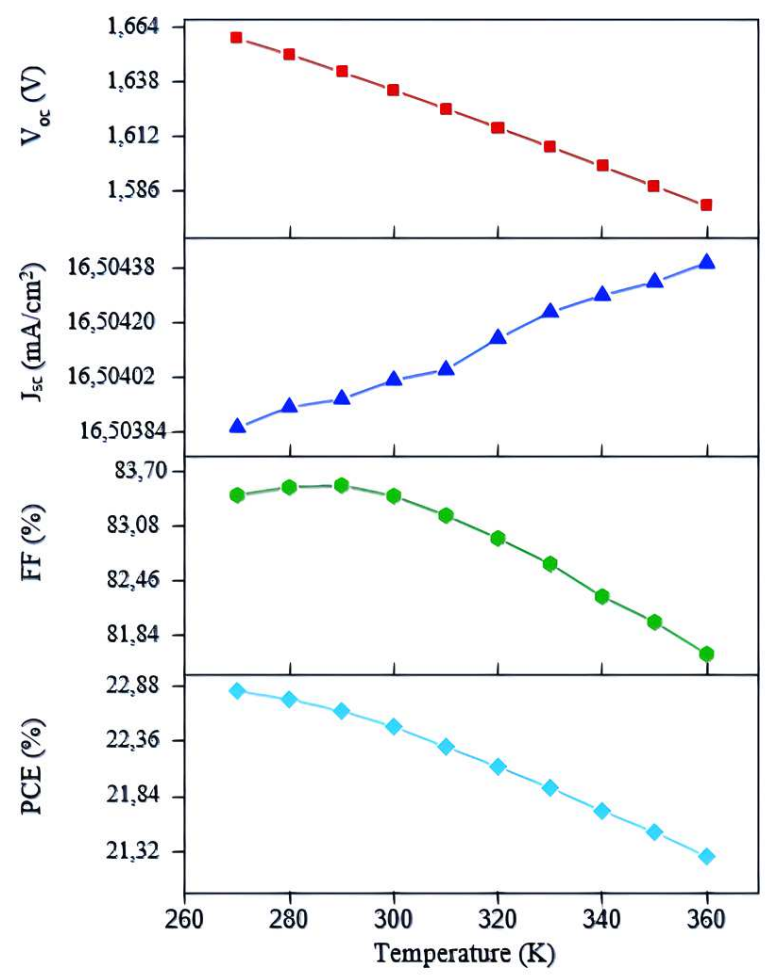

Fig. 15. Output parameters variations for various working temperatures. 


\section{Conclusion}

$\mathrm{FTO} / \mathrm{ZnO} / \mathrm{Cs}_{2} \mathrm{TiI}_{6} / \mathrm{MoO}_{3} / \mathrm{Au}$ has been presented as a new PSC configuration. We presented a highperformance PSC with a PCE of $22.5 \%$ at ambient temperature and $22.84 \%$ at $270 \mathrm{~K}$ based on factors such as charge transport materials and thickness, absorber thickness, absorber defect density, and interface defect density. For a temperature of $270 \mathrm{~K}$, the device performs better, making it ideal for usage in cold areas. The results indicate that $\mathrm{Cs}_{2} \mathrm{TiI}_{6}$ could be useful as an absorber perovskite in highly efficient lead-free inorganic perovskite solar cell technology.

\section{References}

1. M. A. Green, Y. Hishikawa, E. D. Dunlop, D. H. Levi, J. Hohl-Ebinger, M. Yoshita, A. W. Y. Ho-Baillie, Prog. Photovoltaics Res. Appl. 27, 1 (2019)

2. W. Gao, P. Li, J. Chen, C. Ran, Z. Wu, Adv. Mater. Interfaces 6, 24 (2019)

3. I. Chung, B. Lee, J. He, R. P. H. Chang, M. G. Kanatzidis, Nature 485, 7399 (2012)

4. M. M. Lee, J. Teuscher, T. Miyasaka, T. N. Murakami, H. J. Snaith, Science 338, 6107 (2012).

5. M. I. Ahmed, A. Habib, S. S. Javaid, Inter. J. of Phot., 1-13 (2015)

6. W. Ke and M. G. Kanatzidis, Nat. Commun. 10, 1 (2019)

7. A. K. Jena, A. Kulkarni, T. Miyasaka, Chem. Rev. 119, 5 (2019)

8. F. Giustino, H. J. Snaith, ACS Energy Lett.1, 1233-1240 (2016)

9. I. Chung, J. H. Song, J. Im, J. Androulakis, C. D. Malliakas, H. Li, A. J. Freeman, J. T. Kenney, M. G. Kanatzidis., J.A.C.S. 134, 20 (2012)

10. B. V. Lotsch, Angew. Chemie - Int. Ed. 53, 3 (2014)

11. L. Calió, S. Kazim, M. Grätzel, S. Ahmad, Angew. Chemie - Int. Ed. 55, 47 (2016)

12. M. Chen, M. G. Ju, A. D. Carl, Y. Zong, R. L. Grimm, J. Gu, X. C. Zeng, Y. Zhou, N. P. Padture, Joule 2, 3 (2018)

13. M. G. Ju, M. Chen, Y. Zhou, H. F. Garces, J. Dai, L. Ma, N. P. Padture, X. C. Zeng., ACS Energy Lett. 3, 2 (2018)

14. S. Ahmed, F. Jannat, M. A. K. Khan, M. A. Alim, Optik 225, p. 165765 (2021)

15. O. Ahmad, A. Rashid, M. W. Ahmed, M. F. Nasir, I. Qasim, Opt. Mater. 117, p. 111105 (2021)

16. E. Karimi, S. M. B. Ghorashi, Optik 130, 650658 (2017)
17. N. Lakhdar, A. Hima, Opt. Mater. 99, p. 109517 (2020)

18. F. Belarbi, W. Rahal, D. Rached, S. benghabrit, M. Adnane, Optik 216, p. 164743, (2020)

19. S. Pitchaiya, M. Natarajan, A. Santhanam, V. Asokan, A. Yuvapragasam, V. Madurai Ramakrishnan, S.E. Palanisamy, S. Sundaram, D. Velauthapillai., Arab. J. Chem. 13, 1 (2020)

20. Raghvendra, R. R. Kumar, S. K. Pandey, Superlattices Microstruct. 135, p. 106273 (2019)

21. K. Chakraborty, M. G. Choudhury, S. Paul, 194, 886-892 (2019)

22. M.M. Salah, K.M. Hassan, M. Abouelatta, and A. Shaker, Optik 178, 958-963 (2019)

23. T. Minemoto, M. Murata, Sol. Energy Mater. Sol. Cells 133, 8-14 (2015)

24. M. Shahiduzzaman, K. Yamamoto, Y.Furumoto, T. Kuwabara, K. Takahashi, T. Taima, Chem. Lett. 44, 12 (2015)

25. L. Lin, L. Jiang, P. Li, Y. Qiu, Q. Yan, J. Photonics Energy 9, 2 (2019)

26. T. B. Song, T. Yokoyama, C. C. Stoumpos, J. L. Logsdon, D. H. Cao, M. R. Wasielewski, S. Aramaki, M. G. Kanatzidis., J.A.C.S. 139, 2 (2017)

27. T. B. Song, T. Yokoyama, S. Aramaki, M. G. Kanatzidis, ACS Energy Lett. 2, 4 (2017)

28. L. J. Chen, C. R. Lee, Y. J. Chuang, Z. H. Wu, C. Chen, J. Phys. Chem. Lett. 7, 24 (2016)

29. L. J. Chen, RSC Adv. 8, 33 (2018)

30. M. Chen, M. G. Ju, H. F. Garces , A. D. Carl, Luis K. Ono, Z. Hawash, Y. Zhang, T. Shen, Y. Qi, R. L. Grimm, D. Pacifici , X. C. Zeng, Y. Zhou, N. P. Padture, Nat. Commun. 10, 1 (2019)

31. W. Li, J. Li, J. Li, J. Fan, Y. Mai, L. Wang, J. Mater. Chem. A 4, 43 (2016)

32. P. Zhu, C. Chen, S. Gu, R. Lin, J. Zhu, Sol. RRL. 2, 4 (2018)

33. M. A. Green, Sol. Energy 28, 5 (1982)

34. W. Abdelaziz, A. Shaker, M. Abouelatta, A. Zekry, Opt. Mater. 91, 239-245 (2019) 